\title{
„DE GRENZEN DER TOEREKENING” - PROF. DR. C. J. OORT
}

\section{door Prof. Mr. K. Vonk}

De onder bovenstaande titel gehouden oratie van prof. Oort, uitgesproken bij de aanvaarding van zijn ambt van Gewoon Hoogleraar in de Staathuishoudkunde en Statistiek aan de Universiteit te Utrecht, raakt, hoezeer theoretisch van opzet, de actuele situatie. In onderling verband komen in de oratie naar voren een vraagstuk en een stelling. Zij zijn beide vervat in de uitspraak aan het begin: „Elk oordeel over de economische orde en de economische politiek, elk voorschrift voor het overheidsbeleid veronderstelt derhalve een uitspraak omtrent de criteria voor een rechtvaardige inkomensverdeling." In dat ,derhalve" is de stelling uitgedrukt, dat in de economie de vraag naar de gerechtigheid niet minder klemmend aan de orde is dan in de sfeer der rechtsbeoefening. Nog stringenter brengt prof. Oort beide gebieden van wetenschapsbeoefening bij elkaar, wanneer hij zegt, dat de denkbeelden van economisten zowel als van juristen, die zich met de verdelende rechtvaardigheid hebben bezig gehouden, bij nadere analyse blijken te convergeren. Hij onderkent hier een dringende taak voor de wetenschap de gemeenschappelijke normen, die wellicht in het halfduister van politieke leuzen en onbegrepen frazen zijn begraven, aan de oppervlakte te brengen, teneinde de strijd te beperken tor het gebied, waar wezenlijke meningsverschillen bestaan. Terecht, naar het mij voorkomt. Want het vraagstuk, dat in de oratie aan de orde is gesteld, nl. dat van de inkomensverdeling is tegenwoordig niet alleen een vraagstuk van de beginselen der belastingheffing, maar al evenzeer dat van de prijsvorming, waarop de oratie dan ook meer speciaal ingaat, en dus van de marktvormen. In toenemende mate richt zich hierop het economisch beleid en de economische wetgeving. De vraag naar de juiste beginselen, normen en regels en naar hun systematische verbinding, heeft dus practische betekenis. Hiervan legt onder andere getuigenis af de in 1961 verschenen publicatie van de „Deutsche Industrie- und Handelstag”, die in de Franse versie „Assurer notre forme d'existence" voor mij ligt, en onder dit gezichtspunt op blz. 12 en 13 het probleem van marktvorm en inkomensverdeling aanroert. De artikelen 85 en vlgg. van het E.E.G.-verdrag en de zo juist op grond daarvan tot stand gekomen kartelverordening onderstrepen de actualiteit daarvan, evenals de discussies, die gaande zijn, zowel in de Europese Gemeenschap voor Kolen en Staal als in de Europese Economische Gemeenschap terzake van prijsdiscriminatie en prijsdifferentiatie in het vervoer. De kwestie van de juiste normering beweegt de geesten. Markttheoretische concepties en juridische begripsvorming gaan hand in hand of zouden dit althans behoren te doen. In het levendige voorwoord van de onlangs uitgekomen tweede uitgave van Wiles' „Price, Cost and Output” wordt nog eens (p. IX) impliciet het aanrakingsvlak tussen economische theorie, economische politiek en wetgeving geconstateerd. Deze enkele verwijzingen zijn voldoende ter rechtvaardiging van prof. Oorts kanttekening, dat hij blijmoedig naast zich neerlegt het verwijt van grensoverschrijding zijner wetenschap, dat de economist of de jurist dreigt, die zich aan het onderzoek der economische normen zet. De studie dient zich op het leven en niet op de school toe te leggen.

In het betoog wordt de prestatie als bepalend element van de rechtvaardige inkomensverdeling op de voorgrond geplaatst. Daarin wordt aanleiding gevonden

$\mathrm{m}$ a b blz. 121 
de klassieke economie met haar normatief beginsel van recht op het economisch produkt van eigen inbreng te memoreren, en zijn hernieuwd gewaad in de vorm van het "contributief” verdelingsbeginsel van $K$. E. Boulding te omschrijven. Aldus analyserend komen vanzelf de vragen op of de prijs- en inkomensstructuur onder volledige mededinging zowel doelmatig alsook rechtvaardig zijn en welke de grenzen zijn tussen toelaatbare differentiatie en ontoelaatbare discriminatie. Het objectief in de ruil gelegen beginsel verschaft de strikte maatstaf voor een optimale prijs- en inkomensvorming, hetgeen nog geen vrijbrief is voor uitbuiting door economische machtspositie e.d., zodat in bepaalde gevallen slechts door overheidstoezicht aan het beginsel wordt voldaan. Heeft men echter recht op eigen inbreng? Het is deze vraag, die verder wordt onderzocht. De spil, waar alles om draait, is of en hoe de equivalentie van prestatie kan worden benaderd. Is de sociale norm van het uitsluiten van zuivere willekeur en corruptie voldoende? Prof. Oort memoreert de natuurrechtelijke theorieën, die neerkomen op gelijkheid van startvoorwaarden. Hij gaat vooral in op de meer economisch gerichte theorieën, waarbij wordt getreden in de behoeftebevrediging van de individuen, dus in de nutsvergelijking van hun inkomensoverdrachten. Dat de nivelleringstheorie van Jeremy Bentham nog eens wordt verworpen behoeft ons niet te verbazen. Te vermelden is de stelling, dat het begrip maatschappelijke welvaart - en dus maatschappelijk welvaartsmaximum - eerst materiële inhoud krijgt, wanneer het verdelingscriterium reeds is bepaald. Tenslotte komt men dan toch weer uit bij de gelijkheid der individuele welvaartsniveaus als norm, waarbij zowel met productieve inspanning als met verschillen in behoeften rekening wordt gehouden. Uiteraard stuit men op onvergelijkbare subjectieve waardeschattingen, waarbij de vraag wordt behandeld naar het normatieve onderscheid tussen relevante en irrelevante factoren in deze waardeschattingen en hoe de relevante factoren ten opzichte van elkaar moeten worden gewaardeerd. Vooral dit laatste wordt dan aangeduid als te behoren tot het complex vraagstukken van prijsvorming. Daarbij geeft het marktmechanisme wel een antwoord, maar niet steeds een ethisch bevredigend antwoord. Door gemis aan een onafhankelijke waarderingsmaatstaf vormt noch het offerbeginsel - in „Wenkend Perspectief" voorgestaan door het N.V.V. - hiertoe een voldoend uitgangspunt, noch de contributieve verdelingsnorm der klassieken.

Prof. Oort zoekt cen uitweg naar de oplossing van de waarderingsvraagstukken - dus van de rechtvaardige inkomensverdeling - door een combinatie van Tinbergens ruilprincipe en Kranenburgs wet op het rechtsbewustzijn. Tinbergen acht de verdeling van het inkomen rechtvaardig, indien geen enkel individu zijn plaats in de maatschappij zou willen ruilen voor een ander, Kranenburg concludeert, dat zoveel lust en onlust als waarvoor elk de voorwaarden heeft gecreëerd aan hem toekomen. De evidente lacune van het ruilprincipe, nl. dat het geen ondubbelzinnig criterium verschaft ter onderscheiding van de factoren, die wel en die niet bij de ruil moeten worden betrokken, zou worden gevuld door de toerekeningsnormen, voortvloeiend uit Kranenburgs ,,wet”.

Bijna iedere zinsnede van deze laatste bladzijden van Oorts oratie lokt uit tot het plaatsen van kanttekeningen. Ik voor mijzelf geloof niet in Tinbergens ruilprincipe, omdat, om het voorzichtig te zeggen, zeer vele individuen niet te bevredigen zijn: „, wo du nicht bist, dort ist dein Glück.” Anders gezegd, principieel zijn de voorwaarden voor een evenwichtstoestand niet aanwezig. Bovendien is 
in het economisch leven in aanzienlijke mate groepsvorming opgetreden, waardoor ook wezenlijk andere dan individuele factoren zich in het veld van krachten laten gelden (vgl. bijv. André Marchal - Systèmes et structures économiques, Paris 1959, p. 629 vlgg.). Ook naar de zijde van de ethiek laat het ruilbeginsel een spanningsgebied terzijde: het begrip ,offer" uit het economisch ruilproces is anders van inhoud, en wellicht zelfs tegengesteld aan het begrip "offer" uit de ethiek. Met prof. Oort meen ik, dat de normering van het economisch handelen in een samengaan met de rechtswetenschap moet worden gevonden. Kranenburgs "wet" acht ik evenwel niet op te gaan. Het recht gaat niet op in ruilposities. Destijds heeft prof. Paul Scholten in zijn "Algemeen Deel” daarover waardevolle opmerkingen gemaakt. Gelooft men bovendien, dat werkelijk het rechtssubject zijn voorwaarden voor lust en onlust autonoom ,schept"? Is hij niet in zijn handelen, althans ten dele gedetermineerd, en moeten de normen ter beoordeling van zijn verantwoordelijkheid, en voorts, wel te onderscheiden, ter vaststelling van zijn aansprakelijk, niet elders worden gevonden? Kan het optreden in groepsverband en het optreden van beroepen via Kranenburgs formule worden genormeerd? Ik meen van niet.

Terugkerend tot de economie: het zou interessant geweest zijn, indien het uitgangspunt iets meer zou zijn gespecificeerd in zijn toepassing, want dat is het practisch belang van de zaak, al is het wellicht wat onbillijk dit binnen het kort bestek van een oratie te vragen. Hoeveel ruimte moet in het ruilproces aan de inkomensvorming worden gelaten en in hoeverre moet de inkomensverdeling worden gecorrigeerd door belastingheffing, in hoeverre moet met het oog op de inkomensverdeling het ruilproces direct worden gecontroleerd (kartelrecht, prijscontrole), en in hoeverre moeten wellicht de vaste kosten uit de private bedrijfshuishoudingen worden gelicht, teneinde ze niet naar bedrijfseconomische, maar naar sociaal-economische gezichtspunten te verbizonderen of toe te rekenen (vraag, vooral van Franse zijde in het vervoerwezen aan de orde gesteld)?

Dit alles schijnt rijkelijk theoretisch. En toch is de gehele vraag van de normering van direct belang geworden en dus ook de doordenking daarvan.

Hierin ligt het waardevolle van de oratie van prof. Oort. Er zit de nodige overdenkingsstof in en vooral: zij wijst op nut en noodzaak van een synthetische wetenschapsbeoefening.

Het schijnt mij toe, dat „oplossing” hierin ligt, dat de economische wetenschappen de quantitatieve en qualitatieve factoren, die in het economische proces een rol spelen, op hun mérites hebben te onderzoeken, en dat daarnaast de rechtswetenschappen de rechtsbeginselen, de rechtsregels en hun systematiek hebben uit te werken. De normen voor de economische politiek, de economische rechtsregels en de economische jurisprudentie zullen in een spel van vraag en antwoord tussen beide wetenschappen en in de nuchtere praktijk van alledag al doende moeten worden gevonden. Het betreft hier immers verhoudingen in de menselijke samenleving, en die kunnen slechts dialectisch worden benaderd. 